\title{
Nighttime pasture access: Comparing the effect of production pasture and exercise paddock on milk production and cow behavior in an automatic milking system
}

\author{
H. Kismul, ${ }^{1,2 *}$ E. Spörndly, ${ }^{1}$ M. Höglind, ${ }^{3}$ and T. Eriksson ${ }^{1}$ \\ ${ }^{1}$ Department of Animal Nutrition and Management, Swedish University of Agricultural Sciences, 75007 Uppsala, Sweden \\ ${ }^{2}$ Faculty of Biosciences and Aquaculture, Nord University, 7713 Steinkjer, Norway \\ ${ }^{3}$ Norwegian Institute of Bioeconomy Research, 1431, Ås, Norway
}

\section{ABSTRACT}

With increasing intensification of the dairy sector in many countries and with the introduction of automatic milking, exercise paddocks combined with full indoor feeding, as an alternative to production pasture, are being used as a compromise between farm economics and cow welfare. This study examined whether there are production benefits for high-producing dairy cows in an alternative system that uses pasture at a level of approximately $50 \%$ of the total roughage intake in the diet. In an automatic milking system with 12-h night access to the outdoor environment, we compared milk production and behavior of cows in 2 systems: an exercise paddock combined with ad libitum grass silage indoor feeding and a production pasture combined with a restricted daytime grass silage ration. There were 20 cows in the former and 21 cows in the latter system, with the treatments running in parallel. The experiment started in late June with no complete darkness during the night, and lasted for $12 \mathrm{wk}$, with $5.6 \mathrm{~h}$ of darkness at the end. We therefore also explored the effect of night length on milk production and behavior parameters. All cows showed strong motivation for going outdoors and grazing when pasture access was given in early evening, but after a few hours both groups went to the barn and did not return to the pasture area during the remaining night. As the season progressed and nights became longer, cows on the exercise paddock treatment reduced time spent outdoors and grazing time, whereas they increased time spent resting outdoors. The group on exercise paddock had a greater milk yield ( $\mathrm{kg}$ of milk) over the experimental period than the production pasture group. The latter group also showed a greater

Received February 1, 2019.

Accepted July 5, 2019.

*Corresponding author: haldis.kismul@nord.no drop in milk yield over the duration of the trial. Thus, for cows milked in an automatic milking system and offered nighttime outdoor access, no milk production benefits were observed in offering production pasture with restricted indoor silage allowance instead of an exercise paddock with ad libitum silage. We therefore suggest that automatic milking farmers with similar production levels and automatic milking-management systems as in the present experiment, who wish to include grazed grass as part of the dairy cow diet, should ensure that cows have pasture access in the afternoon and evening.

Key words: dairy cow, automatic milking, part-time grazing, milk yield, night grazing

\section{INTRODUCTION}

Dairy farming in high-latitude countries is shaped by a short growing season, cold winter conditions, high labor costs, and strong public interest in animal welfare. As a result, the dairy sector is characterized by a high standard of housing, high yield per cow, increasing herd sizes, and many farms with automatic milking (AM).

When milk yield (MY) and herd size increase, pasture-based milk production often decreases (Huyghe et al., 2017), a common trend in Europe (Hennessy et al., 2015). However, due to consumer preferences (European Commission, 2007; Vanhonacker et al., 2008; Prickett et al., 2010) and animal welfare concerns (Krohn and Munksgaard, 1993; Haskell et al., 2006), grazing is still desirable. Some countries have even introduced welfare legislation that stipulates grazing (e.g., Norway, Sweden, Finland, Switzerland) or a price premium for milk from pasture (e.g., Arla, 2018; FrieslandCampina, 2018).

However, grazing high-yielding cows is challenging, and a reduction in MY is not unusual (Spörndly and Karlsson, 2015), largely due to lower total DMI (Bargo et al., 2003) compared with full indoor nutrient supply. Therefore, grazing is often regarded as nonprofitable 
in high-yielding herds (Swedish Board of Agriculture, 2014), even though pasture is generally cheaper to produce than conserved roughage. However, some studies show that grazing can be profitable even for large dairy herds (Reijs et al., 2013) and in systems where AM is combined with part-time grazing on high-quality pasture (Overrein et al., 2018).

Many farmers reduce the proportion of pasture in the feed ration when shifting from conventional milking to AM (Mathijs, 2004) and some may even cease pasturing entirely (Bühlen et al., 2014). In countries with pasture legislation, it is common to offer cows an exercise paddock (a soft, grass-covered area providing negligible herbage mass) combined with full indoor feeding of high-quality grass silage and concentrates (Swedish Board of Agriculture, 2014; Jørgensen et al., 2015). It has been suggested that exercise paddocks may become an important approach to meet public animal welfare concerns (Bewley et al., 2017).

An alternative strategy to free pasture access is parttime (i.e., restricted) access, where pasture is limited to certain hours, whereas indoor feeding is offered during remaining hours. This provides flexibility, combines the advantages of pasture and indoor feeding, and may even increase grazing efficiency (Kennedy et al., 2009). Daytime pasture access has been studied intensively and has been shown to be a successful strategy for cows in automatic milking systems (AMS; Spörndly et al., 2015; Kismul et al., 2018). However, Charlton et al. (2013) observed higher motivation of cows to go out to pasture at night than in daytime, suggesting that nighttime grazing is an even more beneficial grazing strategy. Northern latitudes, where summer nights are short and light, could perhaps be particularly well suited for night-grazing systems. However, to our knowledge, no previous study has compared different management strategies with nighttime pasture access in an AM barn system.

The aim of the present study was to compare 2 different forage provision systems for high-yielding dairy cows milked in an AM barn during mid-to-late summer with a 12-h nighttime access to the outdoors. The forage provision systems were either a production pasture combined with a restricted grass silage ration offered daytime, or an exercise paddock combined with $24 \mathrm{~h} \mathrm{ad}$ libitum access to grass silage. The research questions addressed were (1) How is MY affected by the outdoor access system? (2) Will cows with production pasture spend more time outdoors compared with cows with access to an exercise paddock? and (3) Will the outdoor behavior be affected by the pronounced changes in night darkness that take place between midsummer and early autumn?

\section{MATERIALS AND METHODS}

The experiment was carried out at the Swedish Livestock Research Centre, Lövsta, Swedish University of Agricultural Sciences, Uppsala, Sweden $\left(59^{\circ} 50^{\prime} \mathrm{N}\right.$, $\left.17^{\circ} 46^{\prime} \mathrm{E}\right)$. Two treatments, where individually fed animals in an AM unit were offered access to either production pasture or an exercise paddock, were run in parallel between June 23 and September 11, 2016. Sunrise and sunset time on the first and longest day of the experiment was 0329 and $2214 \mathrm{~h}$, respectively, whereas on the last and shortest day it was 0609 and $1920 \mathrm{~h}$, respectively. There was no complete darkness during the first night, whereas the last night had 5.6 $\mathrm{h}$ of true darkness. A 1-wk adaptation period preceded the experiment to allow the animals to become accustomed to the treatments. The Uppsala Ethics Committee approved the experimental design and all handling of animals (no. 108 C 20/15).

\section{Barn and Pasture Layout}

The barn (Figure 1) consisted of a resting area with 61 freestalls and 4 concentrate feeders, and a feeding area with 6 water bowls and 20 separate roughage troughs (CRFI, BioControl, Rakkestad, Norway). Roughage feed troughs were placed on weight cells and had access-control gates operated by cow transponders, enabling recording and regulation of feed allowance at the individual cow level, and feed access times $(24 \mathrm{~h}$ or restricted to a given time interval) at the treatment level. Milking was performed using a DeLaval Voluntary Milking System unit (VMS; DeLaval, Tumba, Sweden) consisting of a milking unit with a waiting area.

Indoor cow traffic was controlled in a feed-first manner (DeLaval). Cows moved freely from lying area to feeding area. Upon leaving the feeding area, they had to pass through a 2-way selection gate directing cows due to be milked to the milking unit, and remaining cows back to the resting area. During pasture access hours, cows could exit the barn from both resting and feeding areas to a passage immediately outside the barn door. From this passage, a cow could choose either to continue through a selection gate diverting her to 1 of 2 parallel lanes (each $2 \mathrm{~m}$ wide) leading out to the correct pasture according to treatment, or to re-enter the indoor resting area (Figure 2). Thus, during pasture access hours, cows with milking permission could enter the feeding area and still go to pasture, without having to pass through the milking unit.

Pastures (total 5.8 ha), cow tracks, and the barn itself were situated on a plain field with flat topography (Figure 2), with entrances to exercise paddock and 


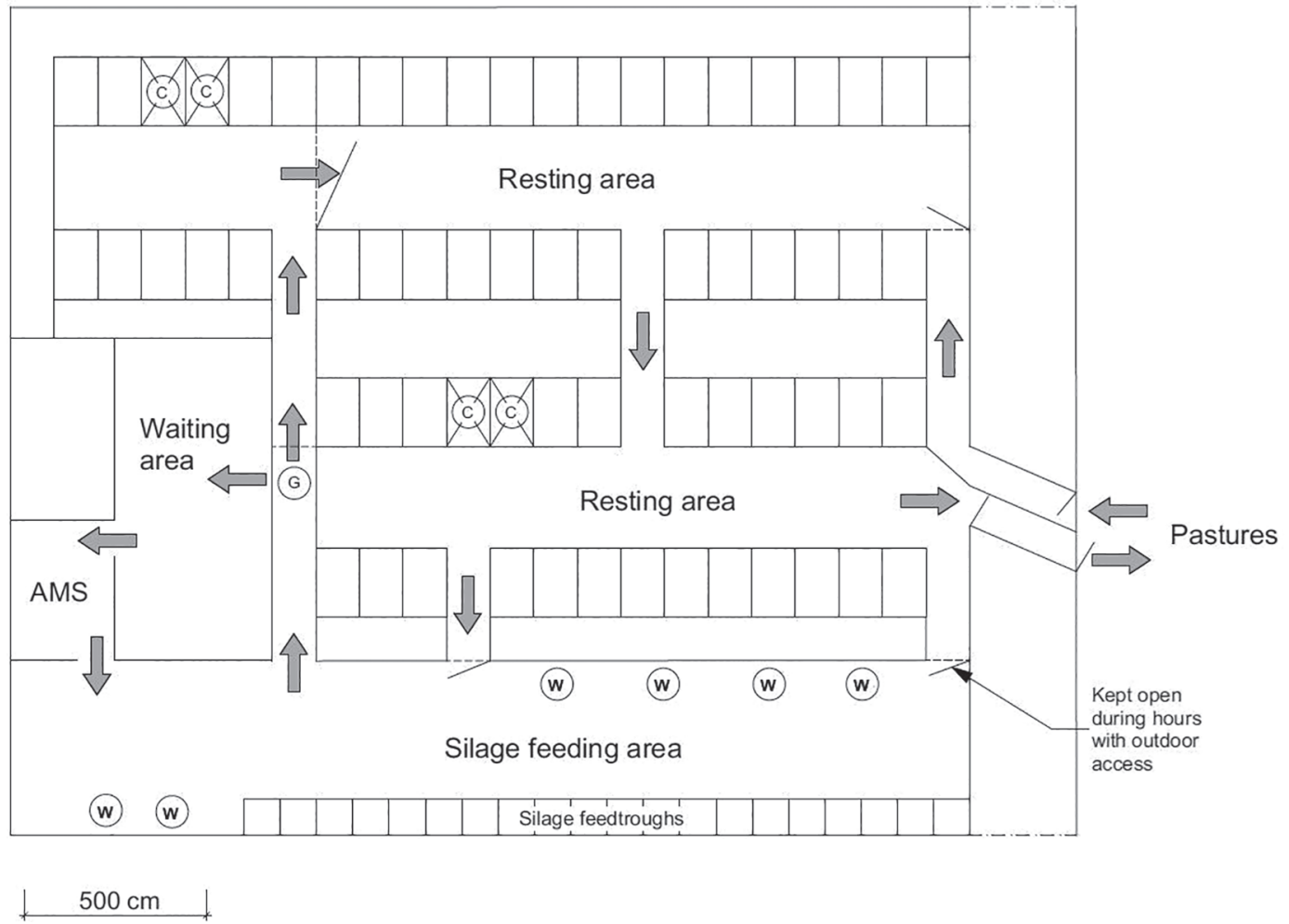

Figure 1. Layout of barn, with exit and entrance to cow lanes leading to pastures. Resting area with 4 concentrate feeders (C), silage feeding area with 20 feed troughs and 6 water bowls $(\mathrm{W})$, and selection gate $(\mathrm{G})$ between feeding, milking, and resting areas. AMS = automatic milking system.

production pastures at a distance of 228 and $228-338$ m (mean $306 \mathrm{~m})$, respectively. Neither the exercise paddock nor the production pastures were visible from the area near the cow barn.

Both the exercise and production pastures were established in 2009, with a seed mixture of $25 \%$ meadow fescue (Festuca pratensis L.), 20\% perennial ryegrass (Lolium perenne L.), $15 \%$ timothy (Phleum pratense L.), 15\% Kentucky bluegrass (Poa pratensis L.), 15\% white clover (Trifolium repens L.), and 10\% red fescue (Festuca rubra L.). At the time of the experiment, timothy had virtually disappeared, whereas the other species were found in various proportions.

\section{Animals, Treatments, Management, and Pasture}

Forty-six cows were selected from the herd at the research farm based upon DIM, MY, and SCC. The animals were blocked into units of 6 cows per block according to parity (primi- and multiparous), preexperimental MY, and breed. Within each block cows were randomly assigned to 1 of 2 treatment groups: exercise paddock (EX) or production (PROD) pasture. During the experiment 5 cows (2 from EX and 3 from PROD) were removed from the experiment due to mastitis (3), leg/claw problems (1), and incorrect automatic registrations (1), leaving 41 cows in the statistical analysis (BW $639 \pm 67 \mathrm{~kg}$, DIM $96 \pm 21$, ECM $34.4 \pm 6.6 \mathrm{~kg} / \mathrm{d}$, milking frequency (MF) $2.1 \pm 0.28$ milkings/d; mean $\pm \mathrm{SD}$ at experiment start). The MY in the covariate period was $3.5 \mathrm{~kg}$ higher for the cows in the PROD group compared with the EX group. The cows were of the breeds Swedish Red (SRB; 26, of which 14 were primiparous) and Swedish Holstein (SH; 15, of which 7 were primiparous). Breed and parity were distributed across the treatments, with 14 SRB (8 primiparous) and $6 \mathrm{SH}$ (3 primiparous) in EX, and $12 \mathrm{SRB}$ (6 primiparous) and $9 \mathrm{SH}$ (4 primiparous) in PROD.

To meet the milking unit capacity, fluctuating numbers of nonexperimental cows (16-20, mean 19) were included in the herd and subjected to the same treatments as their experimental counterparts.

Both treatment groups had outdoor access during a 12-h night period (1800 to $0600 \mathrm{~h}$ ). During the access hours, cows were allowed to move freely between barn and pasture. During remaining hours, both groups were kept indoors with access to same facilities. Drinking water indoors was offered indoors, in the feeding area of the barn. Milking permission was granted $6 \mathrm{~h}$ after the latest milking. At approximately 0630 and $1600 \mathrm{~h}$, 
cows that had not been milked for more than $10 \mathrm{~h}$ were brought to the waiting area of the AM unit.

The EX cows were offered the same 0.2-ha grasscovered paddock throughout the experiment. This was a small, soft area intended as a pleasant place for walking and resting outdoors, but with a negligible amount of pasture intake.

The PROD cows had new pasture allocated by moving an electric fence to give access to at least $15 \mathrm{~kg}$ of DM fresh pasture/cow and day. This gave a theoretical intake of 7.5 to $10.5 \mathrm{~kg}$ of DM pasture/cow and day with 50 to $70 \%$ pasture utilization. On weekdays, the fresh pasture strip was made available once daily, before doors opening in the evening. At weekends, a 3 -d allocation of pasture was made available on Friday evening. The animals were able to back-graze on the allowances of the previous days after the first day in the paddock (Figure 2).

As soon as grazing in a paddock was completed, the sward was mowed to promote homogeneous regrowth.
During the experiment, mean pasture rotation was 40 d. During a long dry spell mid-trial, the pastures were irrigated at irregular intervals. They were also fertilized during the experimental period with mineral $\mathrm{N}$ (40 kg of N/ha, applied once). On 2 separate weekends, adjacent back-up fields were grazed at the same pasture allowance to ensure re-growth of experimental fields.

Both treatment groups were fed the same silage, but with ad libitum 24-h access for EX and a restricted silage ration of $6 \mathrm{~kg}$ of DM/cow and day for PROD (50\% of the ration offered 0600 to $1200 \mathrm{~h}$ and $50 \%$ between 1200 and $1800 \mathrm{~h}$. Unconsumed silage was allowed to carry over from one period to the next within the same day). Silage samples from feed troughs were collected daily and frozen at $-20^{\circ} \mathrm{C}$ for further analysis.

In addition to silage, all animals in both treatment groups were offered an individually adapted concentrate ration according to energy requirements (Spörndly, 2003), using pretrial milk recording and live weight, and an assumption of daily roughage intake (pasture

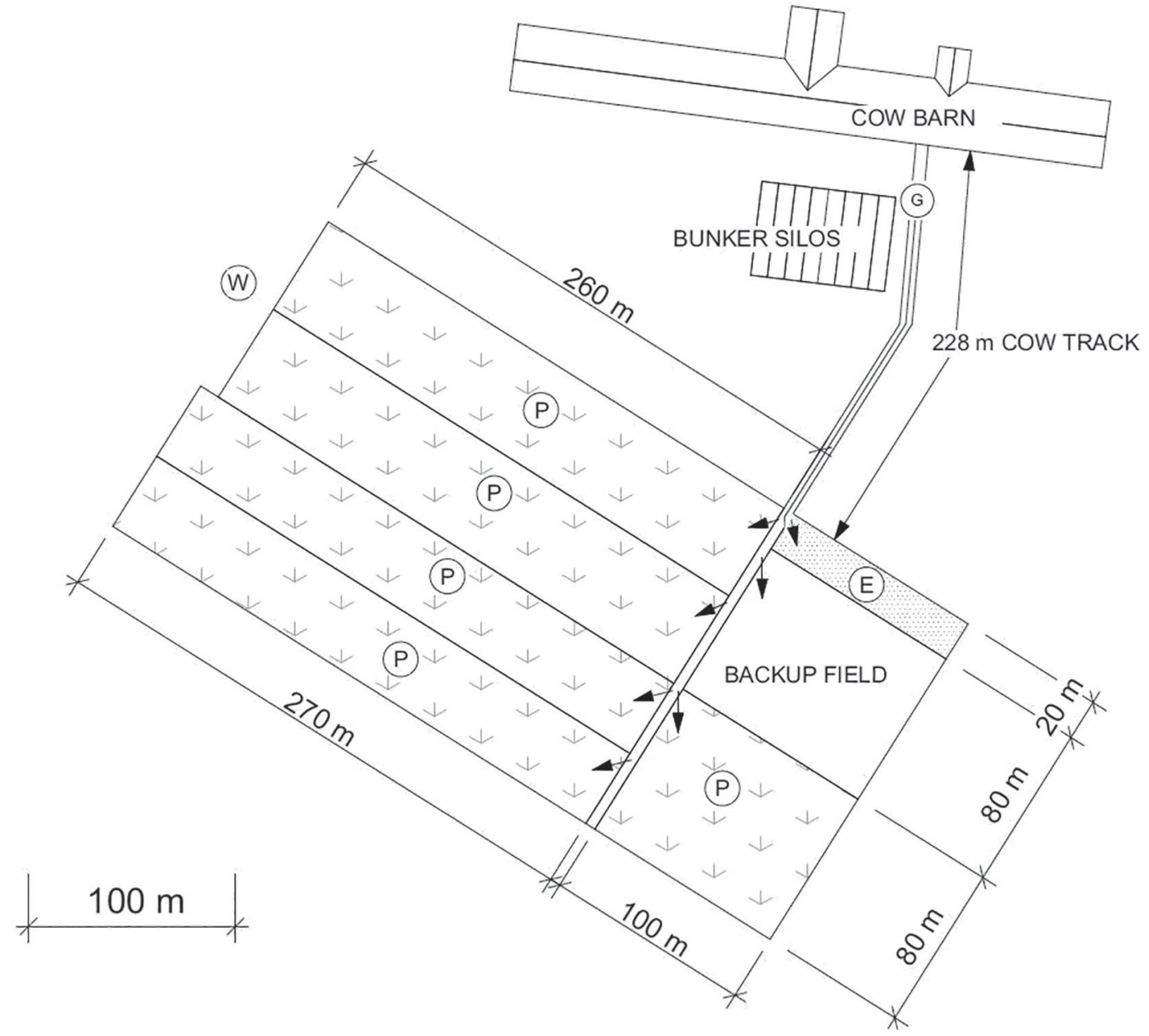

Figure 2. Layout of outdoor area, with cow lanes, selection gate $(\mathrm{G})$, weather station $(\mathrm{W})$, exercise pasture (E), and production pastures (P). 
Table 1. Nutrient content of feeds (mean values, with SE in parentheses)

\begin{tabular}{|c|c|c|c|c|}
\hline Item & Silage & Production pasture & \multicolumn{2}{|c|}{ Concentrate } \\
\hline $\mathrm{DM}, \mathrm{g} / \mathrm{kg}$ & $303(13.5)$ & & $892(4.5)$ & $886(2.3)$ \\
\hline Ash, $\mathrm{g} / \mathrm{kg}$ of DM & $88.8(1.08)$ & $91.8(1.73)$ & $64.2(1.36)$ & $82.1(1.53)$ \\
\hline $\mathrm{CP}, \mathrm{g} / \mathrm{kg}$ of $\mathrm{DM}$ & $127(5.81)$ & $167(6.4)$ & $169(2.57)$ & $279(5.41)$ \\
\hline $\mathrm{NDF}, \mathrm{g} / \mathrm{kg}$ of DM & $504(3.60)$ & $406(6.4)$ & $238(0.1)$ & $268(0.0)$ \\
\hline
\end{tabular}

${ }^{1}$ Komplett Fiber 170 (Lantmännen, Stockholm, Sweden) containing on an as-fed basis (g/kg): small grain mix (barley, oats, wheat), 428; heattreated rapeseed meal, 255; wheat bran, 100; oat hulls, 70; maize grain, 41; vegetable fat, 30; cattle concentrate spillage meal, 24; mineral and vitamin premix, 51; ruminally protected lysine (LysiPearl, Kemin, Des Moines, IA), 0.8; ruminally protected methionine (MetaSmart dry, Kemin), 0.4.

${ }^{2}$ Konkret Mega 28 (Lantmännen) containing on an as-fed basis (g/kg): heat-treated rapeseed meal, 300; soybean meal, 210; beet pulp, 83; wheat bran, 80; palm kernel meal, 78; oat hulls, 40; peas, 37; mineral and vitamin premix, 66; cattle concentrate spillage meal, 30; ruminally protected methionine (MetaSmart dry, Kemin), 2.

${ }^{3}$ Tabulated value from manufacturer.

+ silage) of $12 \mathrm{~kg}$ of DM (10.5 MJ of ME $/ \mathrm{kg}$ of DM). Concentrate ration was adjusted fortnightly throughout according to a standardized lactation curve (Volden, 2011), with an average drop in MY of 0.125 and 0.33 $\mathrm{kg} /$ wk from lactation d 40 onward for primi- and multiparous cows, respectively. The rations were typical for rations that Swedish extension specialists recommend dairy farmers to use during the pasture season. A grainbased concentrate (Komplett Fiber 170, Lantmännen, Stockholm, Sweden) was the basal concentrate. Individuals with pretrial yield $>40 \mathrm{~kg} / \mathrm{d}$ also received a protein supplement (Konkret Mega 28, Lantmännen). Cows received up to $2 \mathrm{~kg}$ of basal concentrate/d in the milking unit, with a maximum of $0.75 \mathrm{~kg}$ per visit. Any remaining ration (including protein supplement) was supplied in the concentrate feeders. Nutrient concentrations in the pasture, silage, and concentrates are presented in Table 1.

\section{Pasture: Measurements, Allocation, and Sampling}

Pregrazing compressed sward height was measured on production pasture using a rising plate meter (Jenquip, Feilding, New Zealand; range $0-26 \mathrm{~cm}$, plate area $0.1 \mathrm{~m}^{2}$; weight $316 \mathrm{~g}$ ) to determine required daily allocation area for the PROD group. To determine sward mass as the season progressed, an updated regression model for the relationship between compressed sward height $(\mathrm{cm})$ and herbage mass $(\mathrm{kg}$ of $\mathrm{DM} / \mathrm{ha})$ at the current development stage of the pasture was applied fortnightly. A set of 20 squares, each $0.25 \mathrm{~m}^{2}$, were measured with the rising plate meter and thereafter cut with electrical clippers (Bosch Iso Cordless Grass shears, Robert Bosch GmbH, Gerlingen, Germany; 3 $\mathrm{cm}$ stubble height). Herbage samples were dried overnight at $60^{\circ} \mathrm{C}$ and weighed, and then sward height was plotted against herbage mass.
On 3 occasions during the experiment (start, middle, end), 10 additional samples were cut for determination of botanical composition and development stage of pasture species. The samples were hand-separated into grass leaf laminae, grass stems (including inflorescences), clover laminae, clover inflorescences (including petioles), dicot weeds, and dead matter. Each fraction was dried overnight at $60^{\circ} \mathrm{C}$ for determination of dry weight.

Every weekday, samples were hand-plucked from the newly allocated pasture area, while aiming to select herbage typical of the strata grazed by the cows. These samples were dried overnight at $60^{\circ} \mathrm{C}$ and stored at room temperature for further analysis.

\section{Recording of Feeding, Animal Production, and Weather}

Each cow was identified with a transponder (DeLaval type B, DeLaval). The $\mathrm{kg}$ of MY and timing of each milking event, intake of silage and concentrates, as well as timing of each feeding occasion were recorded automatically on an individual basis.

Milk samples were collected from each cow and each milking during a 24 -h period (minimum 2 samples/cow and occasion) before experiment start and fortnightly throughout the trial, for analysis of protein, fat, and lactose content by mid-infrared spectroscopy combined with LED cytometry for SCC (Combiscope $600 \mathrm{HP}$, Delta Instruments, Drachten, the Netherlands).

The cows were weighed at the start of the pretrial adjustment period and on the morning after the last behavior observation and milk recording of the experiment.

Outdoor temperature, precipitation, and relative humidity $(\mathbf{R H})$ were recorded instantaneously each hour by a weather station (Vaisala Weather Transmitter 
WXT 510, Vaisala, Vantaa, Finland) situated directly adjacent to the grazing area, approximately $350 \mathrm{~m}$ from the exit to the cow lane (Figure 2 ) and $\sim 1.5 \mathrm{~m}$ above ground. Indoor temperature and $\mathrm{RH}$ were also logged instantaneously each hour (HOBO Pendant Temperature/Light datalogger, Onset Computer Corporation, Bourne, MA) at $\sim 1.5 \mathrm{~m}$. Temperature-humidity index (THI) was calculated according to Kibler (1964), as used in Gantner et al. (2011):

$$
\mathrm{THI}=1.8 \mathrm{AT}-(1-\mathrm{RH})(\mathrm{AT}-14.3)+32,
$$

where AT is ambient (dry bulb) temperature in ${ }^{\circ} \mathrm{C}$ and $\mathrm{RH}$ is relative humidity as a fraction of the unit.

The THI is an indicator of degree of heat stress, a measure incorporating the effects of ambient temperature and $\mathrm{RH}$, as increasing $\mathrm{RH}$ reduce potential of dissipating excess heat through evaporation through skin and lungs. As we made no recordings of other heat stress indicators, and as heat stress was not within the scope of our current study, we chose in this trial to rely on the thresholds from the initial studies conducted in the 1950s at the University of Missouri, regarding THI of 72 as being the threshold where the risk of heat stress is much increased.

\section{Behavior Observations}

Observations of outdoor behavior were performed on all individuals during pasture access hours on one occasion during the preexperimental period and on 6 occasions evenly distributed over the experimental period. On these occasions, scan recordings were made on each cow that was outdoors, at 15-min intervals (Mitlohner et al., 2001) during the 12-h pasture access time. The following observations were recorded at the individual level: (1) location (on cow track, on pasture), (2) body position (standing, lying), and (3) physical activity (grazing, other activities). A cow with 2 or more hooves outside the barn doors was recorded as "on cow track," and a cow with 2 or more hooves over the pasture entrance as "on pasture." Cows in recumbence or in the process of lying down or standing up were recorded as "lying," whereas cows in a position other than lying were recorded as "standing." The activity "grazing" was defined as standing with muzzle to the ground biting off foliage, whereas "other activity" was recorded for any activity other than grazing. When treating the recorded data, "lying position" was defined as the activity "resting," and "other activity" was used to indicate time spent in the standing position and doing any activity other than grazing. Cows not observed on either cow track or pasture were by default defined as being "indoors." Dates for behavior observations were set before experiment start, with the precondition that observation would be postponed if heavy rain was forecast for more than half a pasture access period. Postponement was never needed. To minimize observer influence on the cows' behavior by proximity, conventional and night-vision binoculars were used.

\section{Chemical Analysis of Feeds}

The hand-plucked pasture samples and silage samples from feed troughs were pooled weekly over the experimental periods before drying, milling, and laboratory analysis of DM, ash, Kjeldahl N, ash-free NDF, and $96 \mathrm{~h}$ in vitro digestibility for ME estimation, using standard methods (Eriksson et al., 2012). Dry matter content in silage and pasture herbage was expressed at $103^{\circ} \mathrm{C}$ with no correction for volatiles. Fortnightly pooled samples of silage sampled directly from the silo were used for obtaining silage juice for subsequent determination of $\mathrm{pH}$ and content of fermentation acids and alcohols (Eriksson et al., 2012). Ammonia concentration in the silage juice was determined by flow injection analysis (Fiastar 5010, Tecator, Sweden).

Concentrate samples from the batches fed, taken upon delivery of each new batch, were analyzed using the same methods as for pasture samples for DM, ash, $\mathrm{CP}$, and ash-free NDF.

\section{Calculations and Statistical Analysis}

The ME requirements for both experimental groups were based on experimental MY, BW changes, and estimated walking distances for the 2 treatments and thereafter calculated according to requirements for maintenance, MY, and BW changes taken from national feed tables (Spörndly, 2003) and requirements for activity (NRC, 2001), as described in detail by Kismul et al. (2018).

The ME intake for both treatment groups and the energy balance for EX were calculated from recorded indoor feed intakes and corresponding nutrient contents, whereas 2 pasture intake estimates were made for PROD (one assuming intake covering nutritional needs and one assuming equal energy balance between the groups), as described by Kismul et al. (2018).

Each cow's recorded behaviors were summarized over observation day and divided by 4 to obtain an estimate of the hours spent on the observed activity.

Arithmetic daily means per cow and week were calculated for feed intake, behavior, $\mathrm{kg}$ of milk, and MF. 
Values for ECM (Sjaunja et al., 1990) and for yield of milk fat and milk protein were computed based on milk composition data (fat, protein, and lactose content) combined with hourly MY $(\mathrm{kg})$ recorded on sampling day. Covariates for $\mathrm{kg}$ of milk, ECM, BW, MF, and behavior were obtained using the pretrial recordings.

No statistical analysis was performed on silage or concentrate intake, as allowances were regulated through the experimental design. An ANOVA was performed on milk variables, BW change, and behavior data, using SAS (ver. 9.4, SAS Institute Inc., Cary, NC), with a standard Mixed Model that included class variables: treatment (EX or PROD), parity (primi- or multiparous), and breed ( $\mathrm{SH}$ or SRB); continuous variables: StartDIM (i.e., DIM at experimental start) and week of observation (week), and cow as repeated subject. The response variables analyzed were $\mathrm{kg}$ of milk, $\mathrm{kg}$ of ECM, $\mathrm{kg}$ of milk fat, $\mathrm{kg}$ of milk protein, SCC, number of milkings per day, time spent outdoors, time spent on pasture, and time spent grazing or resting outdoors, using weekly data for all variables. The corresponding variables for milk production or behavior before experimental start were included as a covariate in the model, giving the following general model for all response variables:

$$
\begin{gathered}
\text { response variable }=\text { covariate }+ \text { treatment }+ \text { parity } \\
+ \text { breed }+ \text { StartDIM }+ \text { observation week } \\
+(2 \text {-way interaction, when significant }) .
\end{gathered}
$$

Interactions between variables treatment, parity, breed, StartDIM, and week were tested by backward elimination. When 2-way interactions were significant, these were included in the model. For interactions with week, estimates for the first and last experimental weeks were obtained by the ESTIMATE statement in SAS. The response variable $\mathrm{BW}$ change, which described the weight change during the entire experimental period, was analyzed in a model similar to that described above, but without the variable week and with no repeated measurements. Normality of the residuals was checked through Pearson residuals panel for all analyses. All results presented are least squares means with standard error of the mean. Significance was declared at $P \leq 0.05$. In accordance with the study objectives, results for the response variables are presented with the focus on the effects of treatment and week (i.e., time), and any interactions with these factors. Results with respect to other factors included to improve the model (e.g., breed, parity, and so on) are reported at an overall level.

\section{RESULTS}

\section{Weather, Feed Quality, and Intake}

Average temperature during the experimental period was higher and rainfall was lower than the 30-yr average for the region (Alexandersson et al., 1991), mainly due to warm and dry conditions midway in the experiment. Average indoor and outdoor THI values at different times of day are shown in Figure 3. During pasture access hours, indoor THI was always higher than outdoor THI and mean THI did not exceed the threshold for heat stress (Kibler, 1964). However, for 5 d mid-experiment (July 22-26) the threshold was breached, from 0800 to $1900 \mathrm{~h}$ outdoors and 0900 to $2200 \mathrm{~h}$ indoors.

The average ME content was higher in silage than in production pasture, whereas the content of $\mathrm{CP}$ was lower (Table 1). The content of $\mathrm{ME}$ and $\mathrm{CP}$ in pasture samples was lowest in mid-experiment, reaching 9.8 MJ of ME and $142 \mathrm{~g}$ of $\mathrm{CP}$ per $\mathrm{kg}$ of $\mathrm{DM}$, respectively, before increasing toward the end of the experiment (Table 2). The proportion of grass in the sward was considerably higher in June to July than in September, whereas the proportion of grass stems was highest in June (Table 2). The proportion of clover in the sward rose as the season progressed, with a peak in the proportion of clover inflorescences in July, whereas a considerable proportion of weeds and wilted material was present in the sward at the end of the experiment. Average pregrazing herbage mass was about $2,500 \mathrm{~kg}$ of $\mathrm{DM} /$ ha. Compressed sward height was 12 to $13 \mathrm{~cm}$ on average (Table 2), but substantially higher during late June and lower in August.

Calculated intake of feeds and nutrients is presented in Table 3. Daily silage intake in EX cows was 13.7 $\mathrm{kg}$ of DM, which was higher than the preexperiment assumption of $12.0 \mathrm{~kg}$ of DM. In contrast, intake of silage in PROD cows was slightly below the planned feeding level of $6.0 \mathrm{~kg}$ of $\mathrm{DM} / \mathrm{d}$. Pasture intake in the PROD group was estimated to be between $5.7 \mathrm{~kg}$ of DM per day, calculated at $100 \%$ ME balance and 8.7 $\mathrm{kg}$ of $\mathrm{DM} / \mathrm{d}$ at $112 \% \mathrm{ME}$ balance (as for EX; Table 3 with footnote). Intake of $\mathrm{CP}$ then was higher and intake of NDF was lower in PROD cows than in EX cows, mainly due to differences in $\mathrm{CP}$ and NDF content between silage and pasture (Tables 2 and 3).

\section{Milk Production, Somatic Cell Count, and Milking Frequency}

Milk production data for the EX and PROD treatment groups are presented in Table 4. Daily MY (kg 
milk) based on all milkings during the experiment was higher in EX than in PROD group. A small, but statistically significant, effect as for treatment was observed for the effect of breed on $\mathrm{kg}$ of milk produced, with 33.1 and $31.7 \mathrm{~kg} / \mathrm{d}$ for $\mathrm{SH}$ and SRB breed, respectively $(P=0.0023)$. There was also a parity $\times$ week interaction, with higher MY $(+1.9 \mathrm{~kg})$ for multiparous than primiparous cows in the first experimental week $(P=$ 0.045), but no difference at the end of the experiment.

We did not observe an effect of treatment on the parameters estimated from test milking data [i.e., $\mathrm{kg}$ of ECM, $\mathrm{kg}$ of milk fat, $\mathrm{kg}$ of milk protein, or SCC (Table $4)]$. However, an effect was observed of breed on ECM production (32.9 and $31.2 \mathrm{~kg}$ of ECM for SH and SRB breed, respectively; $P=0.013$ ) and of parity on ECM yield (30.2 and $33.9 \mathrm{~kg}$ of ECM for primiparous and multiparous cows, respectively; $P=0.009$ ).

No effect was observed of treatment on number of milkings per day (Table 4), but an effect of breed was observed (2.24 and 2.35 milkings per day for the $\mathrm{SH}$ and SRB breed, respectively; $P=0.009$ ).

\section{Animal Behavior}

Behavior observations are presented in Table 4. The PROD group spent a longer time outdoors and on pasture, and more hours exhibiting grazing behavior than the EX group, whereas time spent lying down outdoors was shorter for the PROD group. For both treatments, the total outdoor time increased by approximately $1 \mathrm{~h}$ during the course of the experiment (Table 4 footnotes). For EX, a decreased interest in being on pasture for over the experimental period was observed ( 2.5 and $1.9 \mathrm{~h}$ spent on the pasture in the first and last week, respectively). Similarly, time spent grazing by this group decreased from 1.0 to $0.3 \mathrm{~h}$ from start to end of the experiment (Table 4 footnotes). No similar decrease was observed in the PROD group, which spent approximately the same time on the pasture area and grazing over the experimental period. The distribution of outdoor activities and time spent indoors within outdoor access hours (1800-0600 h) for EX and PROD groups are shown in Figures 4A and $4 \mathrm{~B}$, respectively. Over $90 \%$ of the cows in both groups were outdoors at $1900 \mathrm{~h}$ and most were grazing. However, the proportion of cows grazing between 1800 and $2000 \mathrm{~h}$ was substantially higher for PROD than for EX, as EX cows spent comparatively more time resting or idling. The EX cows began to move indoors somewhat earlier than the PROD cows (approximately 2000 and $2100 \mathrm{~h}$, respectively) and concluded their move quickly and in a more synchronized manner, whereas 10 to $20 \%$ of PROD cows lingered outdoors grazing (until $2300 \mathrm{~h}$ ).

Silage intake rate and $\mathrm{MF}$ are presented in Figure $5 \mathrm{~A}$ and $5 \mathrm{~B}$, respectively. Silage intake in EX was quite evenly distributed over the day and night, whereas silage intake in PROD group peaked twice (Figure 5A). The first peak occurred in the morning, when the cows

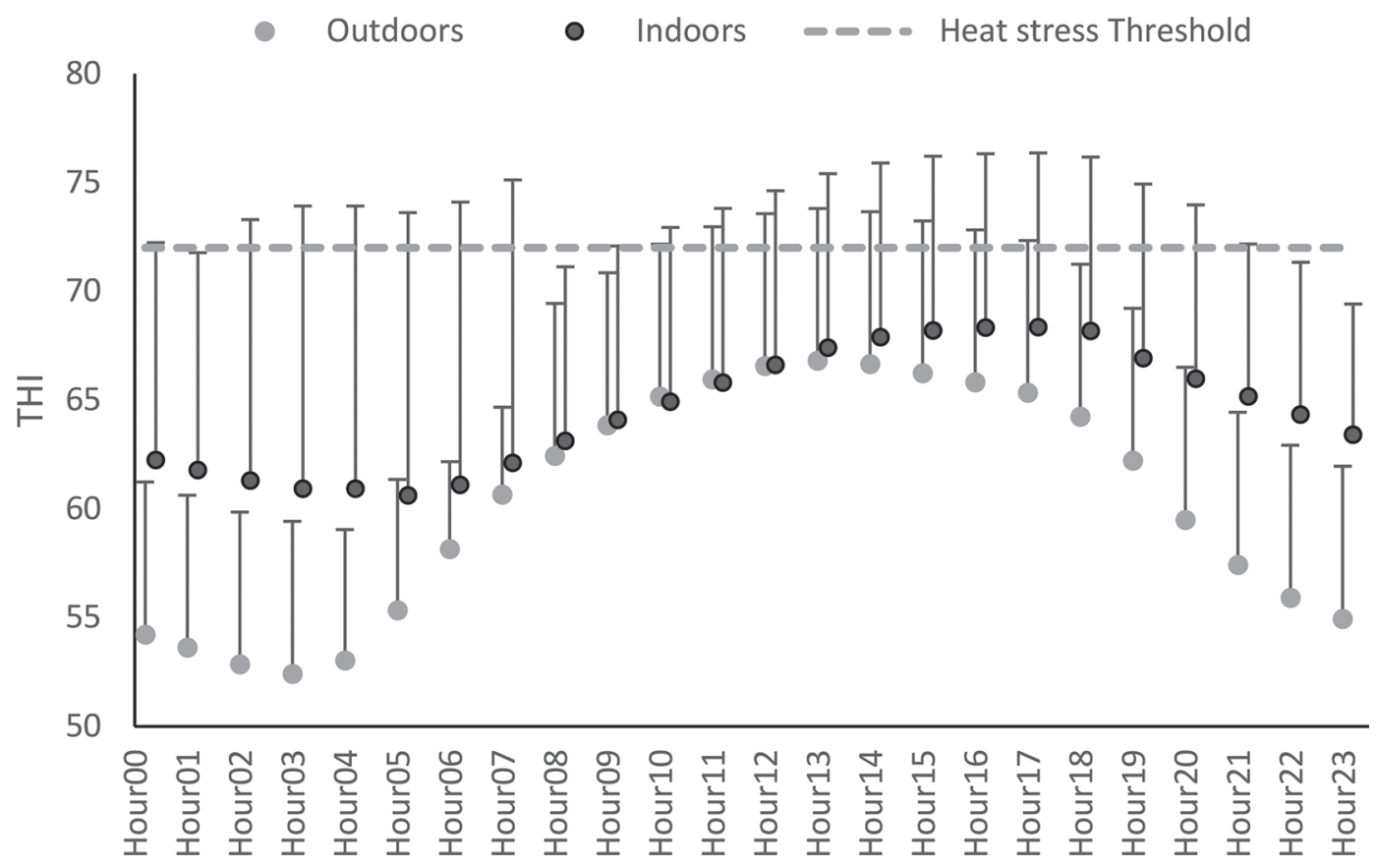

Figure 3. Temperature-humidity index (THI) by hour over $24 \mathrm{~h}$, on average for the trial period, with maximum THI recordings in error bars and THI heat stress threshold indicated (Kibler, 1964). 


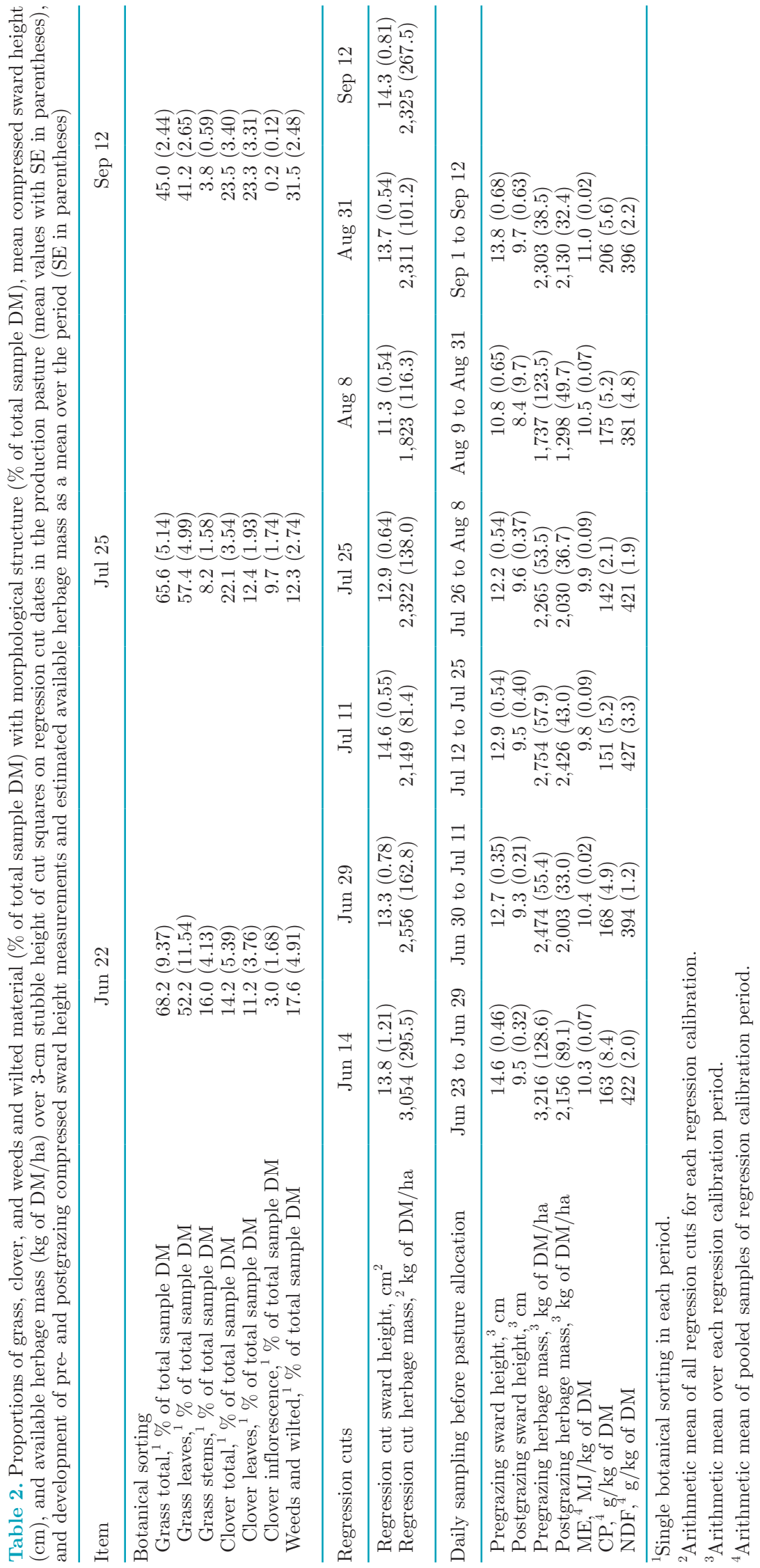


Table 3. Intake of feed and nutrients in the 2 treatment groups (mean values, with SEM in parentheses)

\begin{tabular}{lcc}
\hline & \multicolumn{2}{c}{ Treatment } \\
\cline { 2 - 3 } Item & $\begin{array}{c}\text { Exercise } \\
(\mathrm{n}=20)\end{array}$ & $\begin{array}{c}\text { Production } \\
(\mathrm{n}=21)\end{array}$ \\
\hline Intake of feeds & $13.7(0.35)$ & $5.6(0.02)$ \\
Silage, $\mathrm{kg}$ of DM/d & $6.7(0.27)$ & $7.2(0.34)$ \\
Base concentrate, $\mathrm{kg}$ of DM/d & $1.7(0.14)$ & $1.9(0.15)$ \\
Protein supplement, $\mathrm{kg}$ of DM/d & $0(0)$ & $8.7(0.34)^{1,2}$ \\
Pasture (estimated), ${ }^{1,2} \mathrm{~kg}$ of DM/d & $22.2(0.59)$ & $23.6(0.58)^{1,2}$ \\
Total $\mathrm{kg}$ of DM/d & & \\
Intake of nutrients & $270(7.5)$ & $278(7.4)^{1,2}$ \\
$\mathrm{ME}, \mathrm{MJ} / \mathrm{d}$ & $20.4(0.55)$ & $21.6(0.54)^{1,2}$ \\
$\mathrm{OM}, \mathrm{kg} / \mathrm{d}$ & $3.36(0.10)$ & $3.93(0.11)^{1,2}$ \\
$\mathrm{CP}, \mathrm{kg} / \mathrm{d}$ & $9.0(0.24)$ & $8.5(0.22)^{1,2}$ \\
$\mathrm{NDF}, \mathrm{kg} / \mathrm{d}$ &
\end{tabular}

${ }^{1}$ Assuming same energy efficiency as the exercise group.

${ }^{2}$ Estimating pasture intake as difference between ME requirements (Spörndly, 2003) and ME intake from the feeds, pasture intake would have been $5.7(0.31) \mathrm{kg}$ of DM/d, giving a total nutrient intake of 20.4 $(0.50) \mathrm{kg}$ of DM, $247(6.57)$ MJ of ME, $18.8(0.46) \mathrm{kg}$ of OM, 3.42 (0.10) $\mathrm{kg}$ of $\mathrm{CP}$, and $7.3(0.20) \mathrm{kg}$ of NDF per day.

were given access to silage after the outdoor access period had been terminated at $0600 \mathrm{~h}$. The second peak occurred at noon, when the PROD cows could access the remainder of their daily silage ration. Number of milkings was quite similar for the 2 groups (Figure 5B). A drop in milking frequency was observed for both groups during the first hours after pasture turnout $(1800 \mathrm{~h})$, but this drop was greater and lasted longer for PROD compared with EX cows.

\section{DISCUSSION}

\section{Experimental Period and Pasture Quality}

The Scandinavian summer climate, with relatively long photoperiod and moderately high temperature, is usually favorable for grass growth. However, dry spells occasionally occur during summer (Alexandersson et al., 1991), which may restrict grass growth temporarily. This occurred in the study year, with precipitation in July being substantially lower than the 30 -yr average of the region. Therefore, the differences in nutritional value between the mid-season pasture and the early cut grass silage from primary growth were larger than usual. Although protein content was higher and NDF content was lower in the pasture offered, the average $\mathrm{ME}$ concentration was almost $1 \mathrm{MJ} / \mathrm{kg}$ of $\mathrm{DM}$ lower in pasture compared with silage (Table 1). However, herbage mass was not seriously jeopardized, and with the exception of one sub-period in August, pre- and postgrazing herbage mass was above $2,000 \mathrm{~kg}$ of $\mathrm{DM} /$ ha throughout the experiment (Table 2). Herbage allowance could thus be kept at $15 \mathrm{~kg}$ of $\mathrm{DM} / \mathrm{cow}$ and
Table 4. Effect of exercise (EX) and production (PROD) pasture treatment, breed, and parity on milk production and outdoor behavior parameters (LSM with SEM in parentheses)

\begin{tabular}{lccc}
\hline Item & $\begin{array}{c}\text { EX } \\
(\mathrm{n}=20)\end{array}$ & $\begin{array}{c}\text { PROD } \\
(\mathrm{n}=21)\end{array}$ & $P \leq$ \\
\hline $\begin{array}{l}\text { Production variable } \\
\text { All milkings }\end{array}$ & & & \\
$\quad$ Milk, kg/d & $33.1(0.33)$ & $31.7(0.32)$ & 0.0062 \\
$\quad$ Milkings/d & $2.31(0.031)$ & $2.27(0.028)$ & 0.4031 \\
$\quad$ Test milking days & & & \\
Milk, kg/d & $31.5(0.46)$ & $32.3(0.43)$ & 0.2441 \\
ECM, kg/d & $31.8(0.49)$ & $32.3(0.45)$ & 0.4663 \\
Milkfat, kg/d & $1.27(0.024)$ & $1.30(0.023)$ & 0.5016 \\
Milk protein, kg/d & $1.05(0.015)$ & $1.07(0.014)$ & 0.3933 \\
SCC, log 10 & $1.46(0.057)$ & $1.48(0.056)$ & 0.8113 \\
$\quad$ BW change, kg/wk & $1.7(0.42)$ & $1.0(0.56)$ & 0.1583 \\
Outdoor behavior, h/d $^{1}$ & & & \\
Outdoor time & & & \\
Pasture time $^{3,5}$ & $3.08(0.125)$ & $3.90(0.117)$ & 0.0001 \\
Grazing time $^{6}$ & $2.22(0.077)$ & $2.82(0.071)$ & 0.0078 \\
Lying time $^{7}$ & $0.65(0.067)$ & $2.47(0.063)$ & 0.0001 \\
\hline
\end{tabular}

${ }^{1}$ Based on all visits to the DeLaval Voluntary Milking System (DeLaval, Tumba, Sweden) unit throughout study.

${ }^{2}$ Based on 6 test-milking events evenly spread out through study period.

${ }^{3}$ Outdoor time $=$ total outdoor time (including time in cow lane); pasture time $=$ time on pasture area.

${ }^{4}$ Effect of week $(P<0.0001)$ : outdoor time increases with $0.09 \mathrm{~h} /$ wk. ${ }^{5}$ Effect of 2 -way interaction treatment $\times$ week $(P<0.0005): 2.53$ and $2.62 \mathrm{~h}$ on pasture/d $(P=0.6196)$ for EX and PROD, respectively, at 1st experimental week, 1.93 and $3.01 \mathrm{~h}$ on pasture/d $(P<0.0001)$ for EX and PROD, respectively, at last experimental week, and effect of 2-way interaction treatment $\times$ parity $(P<0.0211) 1.95$ and 2.81 on pasture/d $(P<0.0001)$ for EX and PROD, respectively, for primiparous cows, 2.49 and 2.84 on pasture/d $(P=0.0324)$ for EX and PROD, respectively, for multiparous cows.

${ }^{6}$ Effect of week $(P=0.0198)$ : grazing time increases overall with 0.02 $\mathrm{h} / \mathrm{wk}$, and effect of 2 -way interaction treatment $\times$ week $(P<0.0001)$ : 1.0 and $2.4 \mathrm{~h}$ grazing/d $(P<0.0001)$ for EX and PROD, respectively, at 1st experimental week, 0.3 and $2.6 \mathrm{~h}$ grazing/d $(P<0.0001)$ for EX and PROD, respectively, at last experimental week.

${ }^{7}$ Effect of week $(P=0.0053)$ : lying time outdoors increases overall with $0.036 \mathrm{~h} / \mathrm{wk}$.

day without difficulty. However, compared with a wetter year, the dry spell probably disadvantaged the PROD treatment somewhat by causing lower pasture ME concentration than usual. After the dry spell, rainfall during August promoted re-growth, and improved energy content with a marked increase in clover leaf proportion in the herbage during September (Table 2). The herbage allowance of $15 \mathrm{~kg}$ of DM fresh pasture/ cow and day for the PROD group may have given scope for selection toward higher pasture quality (Johansen and Höglind, 2007).

Pregrazing sward height has an influence on pasture intake as mentioned in the review by Bargo et al. (2003). In the present study, pre- and postgrazing compressed sward height were greater than commonly reported (Phelan et al., 2013; Ganche et al., 2014), but these studies were performed on swards dominated by 

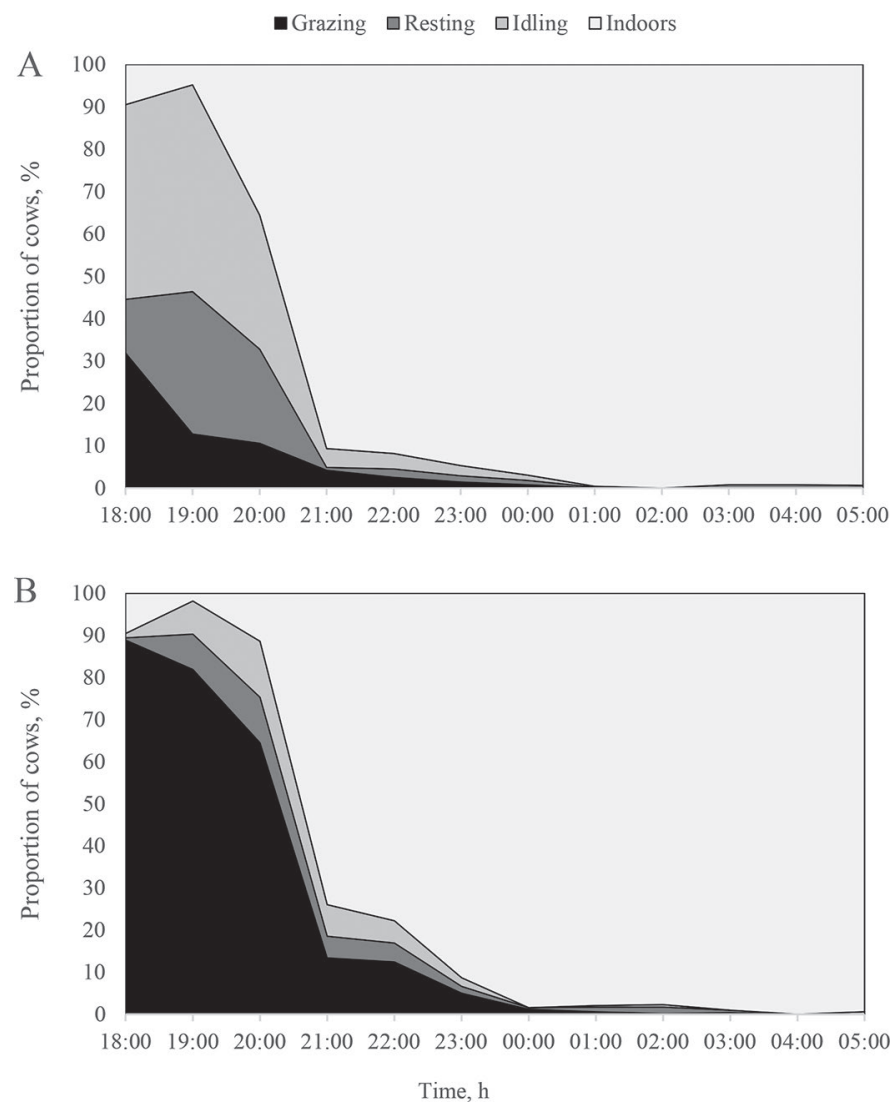

Figure 4. Daily outdoor activity of the groups with exercise paddock (A) and production pasture (B) during pasture access hours; percentage of the group engaged in grazing, resting outdoors, idling (i.e., any upright activities other than grazing), and remaining indoors.

other species than what is commonly found on Scandinavian pastures. Scandinavian pastures are typically composed of species with lower herbage mass per centimeter of sward height than the globally more common ryegrass-dominated pastures (Virkajärvi, 2004). As a result, higher pre- and postgrazing sward heights are recommended for Scandinavian swards (Johansen and Höglind, 2007), and the production pasture in the present experiment was managed according to those recommendations.

\section{Milk Production and Milking Frequency}

Milk yield proved to be $1.4 \mathrm{~kg} / \mathrm{d}$ higher for EX than for PROD cows (Table 4).

The lower ME density in pasture versus silage was probably a contributing factor. In a similar experiment performed in a tiestall barn, cows allowed to night grazing pasture with higher ME concentration than the silage fed to a control group indoors, responded with $3.9 \mathrm{~kg} / \mathrm{d}$ larger MY (Sairanen et al., 2006). However, the outcome of this kind of experiment may not be a simple and direct effect of the nutritional densities in the feeds. The current experiment was performed in an AM barn where cow behavior, motivation, and choice has a strong influence. The current experiment can be compared with our previous experiment with 2 separate session (morning and evening) of pasture access arranged with similar design and similar relative $\mathrm{ME}$ difference between pasture and silage (Kismul et al., 2018). In that experiment, MY did not differ between cows on exercise paddock and production pasture, respectively, but grazing time on production pasture was considerably longer in that experiment, $3.8 \mathrm{~h} / \mathrm{d}$, versus $2.5 \mathrm{~h} / \mathrm{d}$ in the current experiment. This suggests an ability to compensate to some extent for lower nutritional density if the cows use more of the allowed grazing time, perhaps then in combination with more selective grazing.

The $2.5 \mathrm{~h}$ of active grazing occurred during the evening with no grazing and thus no further roughage intake at nighttime. The period around dawn is often a major grazing period (Gibb et al., 1998; Rook, 2000; Taweel et al., 2004; John et al., 2017) and it is remarkable that cows in our experiment refrained from grazing at dawn, despite the presence of sufficient pasture to graze (Table 2). The potential for increased pasture intake with nighttime grazing that was suggested by Charlton et al. (2013) and indicated in our previous experiment (Kismul et al., 2018) was thus not realized.

Although the pasture DMI rate was probably high in the first few hours after the cows were allowed access to the outdoor area, it is likely that the absence of pasture and silage intake during the rest of the night limited MY in PROD compared with EX cows. If grazing is induced each time cows are given access to pasture, this would also explain why the grazing time was $3.8 \mathrm{~h} / \mathrm{d}$ in our previous experiment with morning and evening pasture sessions with a total outdoor access time of 8.5 h (Kismul et al., 2018), but only $2.5 \mathrm{~h}$ in the present experiment, where outdoor access time was $12 \mathrm{~h}$. The short grazing time observed in this study supports the recommendation by Kennedy et al. (2009) to split parttime grazing into a minimum of 2 sessions to maximize grazing.

The milk production results thus indicate that in this type of night-grazing AM-management system, a similar production level as with ad libitum indoor feeding of high-quality silage may not be achieved, because of reluctance to use pasture access hours after the evening grazing session. Despite the $1.4 \mathrm{~kg}$ MY difference in favor of EX cows during the experimental period (Table 4), estimations of economical outcome based on models from similar management systems show that produc- 
tion results from offering production pasture would still be profitable in Norway and Sweden (Overrein et al., 2018).

The lack of differences in MF between the 2 groups is in strong contrast to findings in previous part-time grazing trials at our research unit (Spörndly et al., 2015; Kismul et al., 2018), where PROD cows consistently showed less frequent visits to the AM unit than EX cows. This lack of difference in MF in the present experiment is most likely attributable to the very short time spent outdoors for both treatment groups, leaving plenty of time for individuals to maintain similar activities in the barn as in the indoor season.

We observed no effect of treatment on the parameters estimated from test milking data. This is a common challenge in animal production studies, as discussed in Huhtanen and Hetta (2012). Due to either economical or practical feasibility, sample sizes are frequently too small to detect economically important differences in traits by nature highly variable.

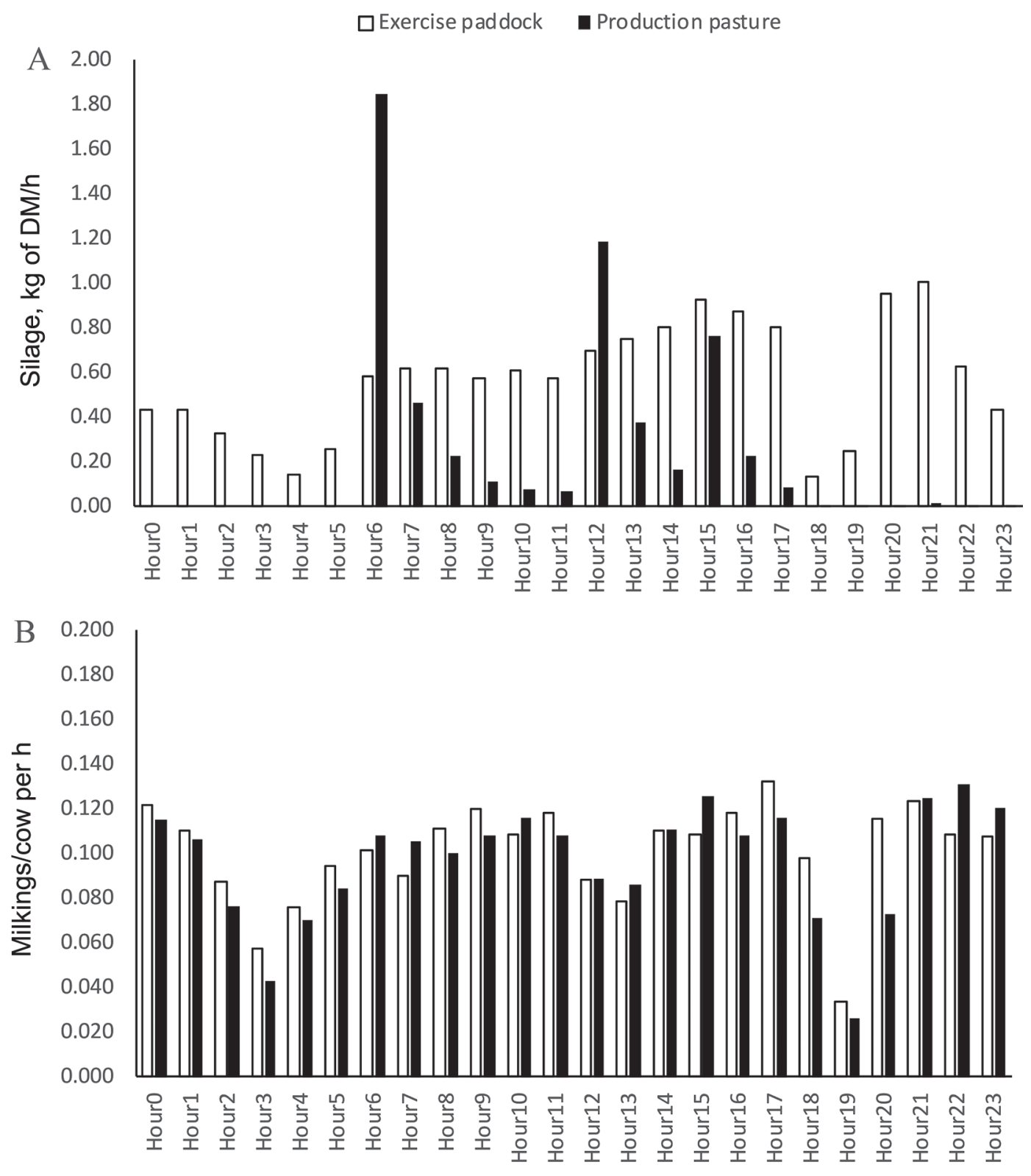

Figure 5. Average group silage intake as kilograms of DM silage per cow (A) and milking frequency as milkings per cow (B), both by hour over $24 \mathrm{~h}$ and across the trial period for the exercise and production pasture groups. 


\section{Pasture Intake}

Whereas active grazing time was much shorter than expected, it can be assumed that pasture DMI rate was high. Restricted outdoor access has been shown to increase grazing intensity and pasture intake rate per hour compared with unrestricted access (Chilibroste et al., 1997; Kennedy et al., 2009; Pérez-Ramírez et al., 2009). The timing of pasture access from $1800 \mathrm{~h}$ would probably also promote high pasture DMI rate, as it coincides with the peak for bite rate and DMI rate observed by Gibb et al. (1998).

Estimates of pasture DMI ranged from $5.7 \mathrm{~kg}$ of DM/d at $100 \% \mathrm{ME}$ balance to $8.7 \mathrm{~kg}$ of $\mathrm{DM} / \mathrm{d}$ at $112 \% \mathrm{ME}$ balance (as for EX; Table 3), based upon feed analyses, tabulated requirements (Spörndly, 2003; NRC, 2001), recorded ECM yields, and live weight changes (Table 4). The highest value of $8.7 \mathrm{~kg}$ of $\mathrm{DM} / \mathrm{d}$ is equal to that estimated in our previous experiment (Kismul et al., 2018), where actual grazing time was $53 \%$ longer and corresponds to a pasture DMI of $3.5 \mathrm{~kg} / \mathrm{h}$. This exceeds most literature values, although Chilibroste et al. (1997) report pasture DMI rates up to $3.6 \mathrm{~kg}$ of DM/h. Hence, even our highest estimate cannot be ruled out considering the favorable conditions for high DMI during a limited time, but a more conservative estimate is that the true pasture DMI was within the range 5.7 to $8.7 \mathrm{~kg}$ of $\mathrm{DM} / \mathrm{d}$.

\section{Silage Intake}

The EX cows in the present experiment consumed silage throughout the $24 \mathrm{~h}$, whereas there was a long period when PROD cows consumed neither silage nor pasture (Figures 4 and 5). The ad libitum access to high-quality silage resulted in an intake rate in the EX group of approximately $14 \mathrm{~kg}$ of DM/d (Table 3), comparable to that of the EX cows in our previous experiment (Kismul et al., 2018). Having more or less finished their silage allowance around $1600 \mathrm{~h}$ and choosing to stay indoors for $\sim 8 \mathrm{~h}$ each night $(\sim 2200$ to $0600 \mathrm{~h})$, the PROD cows in the present experiment indirectly chose to refrain from eating roughage in this period. In the same period, the EX cows made a steady stream of visits to their feed troughs, ingesting on average $0.4 \mathrm{~kg}$ of DM silage/cow and hour. In the first morning hour with silage access, PROD cows showed great motivation for roughage intake, eating approximately $1.8 \mathrm{~kg}$ of DM/cow and hour (Figure 5).

\section{Behavior}

Outdoor Time Budget. Motivation to be outdoors, when given the choice, is complex and influenced by a number of factors such as distance to pasture, time of day, previous experience, and location of water and feed (Charlton and Rutter, 2017). With a restricted silage allowance during daytime only and fresh pasture allowed at nighttime at $15 \mathrm{~kg}$ of $\mathrm{DM} / \mathrm{cow}$ and day, it was expected that PROD cows would graze more than the time actually recorded, whereas EX cows would have little reason to graze on the negligible vegetation available in the pasture on offer. However, despite a high indoor intake of ME (Table 3), EX cows still spent $0.65 \mathrm{~h} / \mathrm{d}$ grazing, biting off the occasional grass-stem in the exercise paddock, a behavior that is in accordance with observations made in earlier experiments with exercise-type pasture (e.g., Charlton et al., 2013; Kismul et al., 2018).

The PROD group maintained a similar grazing time during the experiment, 2.4 and $2.6 \mathrm{~h}$ in the early and late experimental week, respectively, whereas grazing time for EX cows decreased from 1.0 to $0.3 \mathrm{~h}$ (Table 4). A plausible explanation for the declining expression of grazing behavior by EX cows is that the concentrated fouling in the small exercise paddock as the experiment progressed made the cows more reluctant to graze (Spörndly, 1996).

Synchronization. Synchronization of cow behavior may be regarded as a problem in many grazing experiments (Rook and Huckle, 1995) because behaviors are not expressed independently of other individuals. In the present experiment, almost all PROD cows left the barn and entered the pasture within the first hour of pasture access and began grazing in a synchronous manner (Figure 4B). As most of the group had finished their silage ration at around $1500 \mathrm{~h}$, this synchronized behavior might have been motivated largely by hunger. Restricting access hours to pasture per se has also previously been observed to promote this type of synchronization (Kismul et al., 2018). The EX cows were less synchronized in their feeding behavior (Figure 4A), with some cows remaining indoors during the first hour of outdoor access, whereas others engaged in different outdoor activities.

As in our previous study (Kismul et al., 2018), there was no sign of the circadian eating rhythm, with a smaller eating event around dawn and a larger one around dusk, reported by others (e.g., Gibb et al., 1998; Rook, 2000; Taweel et al., 2004; John et al., 2017; Figure 4). Both groups had their largest grazing bout in the evening, whereas no cows were on pasture or even outdoors in the morning.

Motivation to Be on Pasture and Outdoor Comfort. Considering PROD group's long absence from any roughage intake, one could expect these cows to experience hunger in the early morning and have a strong motivation for grazing. Behavior observations 
showed that the PROD cows preferred to wait for their silage allowance instead of engaging in grazing. This may be due to a lower palatability of morning grass, which has a high water content and low content of soluble sugars (Delagarde et al., 2000), but it could also be due to the walking distance to pasture, which has been shown to have an effect on cow motivation (Spörndly and Wredle, 2004).

The total absence of cows sleeping or resting on pasture contradicts observations in several other experiments, where cows in AMS spent 80 to $100 \%$ of their resting time outdoors (Ketelaar-de Lauwere et al., 1999), and specifically, 77 to $81 \%$ of nighttime outdoors (Charlton et al., 2013). The opportunity to lie down on pasture has been identified as an important welfare asset (Krohn and Munksgaard, 1993; Charlton and Rutter, 2017), but apparently our cows were not motivated to make use of this opportunity.

The present experiment took place during an uncharacteristically warm, dry summer compared with average Scandinavian conditions. Temperatures and THI remained high indoors throughout the night, but dropped substantially outdoors. It was therefore surprising that cows chose not to stay on pasture for the night just to rest in a cooler environment.

Although night pasture generally has a comparatively high water content, it is probable that lack of drinking water on pasture was one of the factors that contributed to the short time spent outdoors. Despite finding no overall effect, Spörndly and Wredle (2005) observed a behavior effect from providing water on pasture during one experimental period. Another important motivation for cows to stay indoors was the concentrate supplements that were offered indoors. This cannot be overestimated, as shown by the results of Prescott et al. (1998).

In a review by Lyons et al. (2014) about factors that affect the voluntary milking frequency in AMS, it has been suggested that there is an element of habituation in the choices made by dairy cows depending on housing system. It seems probable that cows accustomed to being fed and managed indoors during 8 mo per year often choose to return indoors during the pasture season, especially if this is where they are offered water and concentrates.

Possible Responses to Day Length. In Scandinavia, day length varies greatly over the year, with short or even no night around midsummer and a rapid decrease in day length during autumn to long midwinter nights. This experiment started just $2 \mathrm{~d}$ after the longest day of the year, when there was nautical twilight (sun $6-12^{\circ}$ below the horizon) and therefore it was never actually dark to the human eye (National Imagery and Mapping Agency, 2017). The final night of the experiment lasted for $10 \mathrm{~h} 48 \mathrm{~min}$, of which $5.6 \mathrm{~h}$ were outside astronomical twilight (i.e., sun more than $18^{\circ}$ below the horizon) with complete darkness to the human eye (National Imagery and Mapping Agency, 2017). As the nights grew longer and darker, we expected a seasonal decrease in time spent outdoors and, for the PROD group, in time spent grazing. However, from the start to the end of the 12-wk experiment, time spent on pasture increased $1 \mathrm{~h}$. Even though this is less than $10 \%$ of the total 12 -h outdoor access time, it is still approximately 25 to $30 \%$ of the average time spent outdoors by the treatment groups.

According to Albright (1993), presence of twilight influences cows more than the actual hour of the day. However, limited or no information is available on the lower limit of light that a cow can detect, and thus we do not know how dark it needs to be for cows to perceive it as dark. With their dichromatic vision (Jacobs et al., 1998), close to $360^{\circ}$ vision, large pupils, and powerful tapetum lucidum (Prince et al., 1960), it seems reasonable to assume that cows have better night vision than humans. This was also observed in a test at our laboratory in which cows had to pass through an obstacle course at varying light intensities to reach a reward (Ferneborg et al., 2014). Even with light intensities down to $0 \mathrm{~lx}$, the cows still managed to pass through without refusals or knockdowns, although step frequency, step length, number of stops, and time needed to pass through an obstacle were slightly affected. It is therefore quite likely that the cows in the present experiment saw well enough to use pasture during the night, even though day length decreased substantially with time.

\section{CONCLUSIONS}

Milk yield ( $\mathrm{kg}$ of milk) based on all milkings throughout the experimental period was higher for cows on an exercise paddock allowed ad libitum silage (EX group) than for cows on pasture at night and allowed restricted amount of silage at daytime (PROD group). All cows spent only a few hours outdoors in the early evening and thereafter returned to the barn for the rest of the night. They did not use the possibility of resting outdoors, where it was cooler, and they did not graze in the early morning hours, not even around midsummer when the nights were light. Thus, for farmers with AM equipment, indoor feeding appears more advantageous in a nighttime grazing system. Cows were eager to graze in the early evening, but for the rest of the night the pasture was not used by the cows, which is probably the reason for the lower MY in PROD cows. To promote grazing and animal welfare, we therefore suggest that farmers, with similar production levels and 
AM-management systems as in the present experiment, who wish include grazed grass as part of the dairy cow diet should ensure that cows have pasture access in the late afternoon and evening.

\section{ACKNOWLEDGMENTS}

We thank Eva Rundlöf at the Swedish University of Agricultural Sciences Livestock Research Centre barn (Uppsala, Sweden) for technical aid with facilities, the barn staff for herd management, and the Department of Animal Nutrition and Management (Uppsala, Sweden) laboratory staff for manning and running the laboratory during the summer holidays. The assistance of Rainer Nylund, Department of Animal Nutrition and Management (Uppsala, Sweden) with pasture maintenance and contributions by master's student Hanna Blomberg, Department of Animal Nutrition and Management (Uppsala, Sweden), and student intern Jessica Perette (Montpellier SupAgro, Montpellier, France) to experimental work and behavior observations are gratefully acknowledged. This work was funded by the Swedish Farmers' Foundation for Agricultural Research (Stockholm, Sweden; grant number V14-0016) and the Norwegian Research Council (Oslo, Norway; project no. 234764), with no further involvement in the project that could have influenced the outcome of the research.

\section{REFERENCES}

Albright, J. L. 1993. Feeding behavior of dairy cattle. J. Dairy Sci. 76:485-498.

Alexandersson, H., C. Karlström, and S. Larsson-McCann. 1991. Temperature and precipitation in Sweden 1961-90 (In Swedish). The Swedish Meteorological and Hydrological Institute (SMHI), Norrköping, 1-88.

Arla. 2018. Arla launches Summermilk ${ }^{\circledR}$ products with longer time on pasture during the summer (In Swedish). Accessed Jan 15, 2019. http://www.mynewsdesk.com/se/arla/pressreleases/arla-lanserar -sommarmjoelk-r-produkter-och-laengre-sommarbete-2481223.

Bargo, F., L. D. Muller, E. S. Kolver, and J. E. Delahoy. 2003. Invited Review: Production and digestion of supplemented dairy cows on pasture. J. Dairy Sci. 86:1-42.

Bewley, J. M., L. M. Robertson, and E. A. Eckelkamp. 2017. A 100Year Review: Lactating dairy cattle housing management. J. Dairy Sci. 100:10418-10431.

Bühlen, F., S. Ivemeyer, C. Krutzinna, and U. Knierim. 2014. Potential effects of automatic milking systems on grazing in organic dairy farming. Org. Agric. 4:301-308.

Charlton, G. L., and S. M. Rutter. 2017. The behaviour of housed dairy cattle with and without pasture access: A review. Appl. Anim. Behav. Sci. 192:2-9.

Charlton, G. L., S. M. Rutter, M. East, and L. A. Sinclair. 2013. The motivation of dairy cows for access to pasture. J. Dairy Sci. 96:4387-4396.

Chilibroste, P., S. Tamminga, and H. Boer. 1997. Effects of length of grazing session, rumen fill and starvation time before grazing on dry-matter intake, ingestive behaviour and dry-matter rumen pool sizes of grazing lactating dairy cows. Grass Forage Sci. 52:249-257.

Delagarde, R., J. L. Peyraud, L. Delaby, and P. Faverdin. 2000. Vertical distribution of biomass, chemical composition and pepsin-cel- lulase digestibility in a perennial ryegrass sward: interaction with month of year, regrowth age and time of day. Anim. Feed Sci. Technol. 84:49-68.

Eriksson, T., L. Norell, and N. Nilsdotter-Linde. 2012. Nitrogen metabolism and milk production in dairy cows fed semi-restricted amounts of ryegrass-legume silage with birdsfoot trefoil (Lotus corniculatus L.) or white clover (Trifolium repens L.). Grass Forage Sci. 67:546-558.

European Commission. 2007. EU consumers willing to pay for better animal welfare. European Commission, Brussels. Accessed Jan. 25, 2019. http://europa.eu/rapid/press-release_IP-07-398_en.htm.

Ferneborg, S., J. Eriksson, P. Olsson, S. Agenäs, and E. Ternman. 2014. Effect of low light intensity on stress indicators in dairy cows. Proc. Aust. Soc. Anim. Prod. 30:152.

FrieslandCampina. 2018. Milk price explained - 2018. Accessed Jan. 15, 2019. https://www.frieslandcampina.com/en/organisation/ financials/milk-price-explained/.

Ganche, E., L. Delaby, M. O'Donovan, T. M. Boland, and E. Kennedy. 2014. Short term response in milk production, dry matter intake and grazing behavior of dairy cows to changes in postgrazing sward height. J. Dairy Sci. 97:3028-3041.

Gantner, V., P. Mijić, K. Kuterovac, D. Solić, and R. Gantner. 2011. Temperature-humidity index values and their significance on the daily production of dairy cattle. Mljekarstvo 61:8.

Gibb, M. J., C. A. Huckle, and R. Nuthall. 1998. Effect of time of day on grazing behaviour by lactating dairy cows. Grass Forage Sci. $53: 41-46$.

Haskell, M. J., L. J. Rennie, V. A. Bowell, M. J. Bell, and A. B. Lawrence. 2006. Housing system, milk production, and zero-grazing effects on lameness and leg injury in dairy cows. J. Dairy Sci. 89:4259-4266.

Hennessy, D., L. Delaby, A. Van den Pol-Van Dasselaar, and L. Shalloo. 2015. Possibilities and constraints for grazing in high output dairy systems. Grassl. Sci. Eur. 20:151-162.

Huhtanen, P., and M. Hetta. 2012. Comparison of feed intake and milk production responses in continuous and change-over design dairy cow experiments. Livest. Sci. 143:184-194.

Huyghe, C., A. Van den Pol-Van Dasselaar, and A. Krause. 2017. Evaluating the current conditions and challenges of livestock grazing in France and Europé. Fourrages (Versailles) 229:1-10.

Jacobs, G. H., J. F. Deegan, and J. A. Y. Neitz. 1998. Photopigment basis for dichromatic color vision in cows, goats, and sheep. Vis. Neurosci. 15:581-584.

Johansen, A., and M. Höglind. 2007. Herbage intake, milk production and sward utilization of dairy cows grazing grass/white clover swards at low, medium and high allowances. Acta Agric. Scand. A Anim. Sci. 57:148-158.

John, A. J., S. C. Garcia, K. L. Kerrisk, M. J. Freeman, M. R. Islam, and C. E. F. Clark. 2017. Short communication: The diurnal intake and behavior of dairy cows when access to a feed of consistent nutritive value is restricted. J. Dairy Sci. 100:9279-9284.

Jørgensen, G. H. M., S. M. Eilertsen, I. Hansen, and L. Aanensen, 2015. The behaviour and production of dairy cattle when offered green pasture or exercise pen. Pages 107-109 in Proc. EGF 2015 Grassland and forages in high output dairy farming systems. Wageningen Academic Publishers, Wageningen, the Netherlands.

Kennedy, E., M. McEvoy, J. P. Murphy, and M. O'Donovan. 2009. Effect of restricted access time to pasture on dairy cow milk production, grazing behavior, and dry matter intake. J. Dairy Sci. 92:168-176.

Ketelaar-de Lauwere, C. C., A. H. Ipema, E. N. J. van Ouwerkerk, M. M. W. B. Hendriks, J. H. M. Metz, J. P. T. M. Noordhuizen, and W. G. P. Schouten. 1999. Voluntary automatic milking in combination with grazing of dairy cows: Milking frequency and effects on behaviour. Appl. Anim. Behav. Sci. 64:91-109.

Kibler, H. H. 1964. Thermal effects of various temperature-humidity combinations on Holstein cattle as measured by eight physiological responses. Research Bulletin Missouri Agricultural Experiment Station 862:1-42.

Kismul, H., E. Spörndly, M. Höglind, G. Næss, and T. Eriksson. 2018. Morning and evening pasture access - Comparing the effect of pro- 
duction pasture and exercise pasture on milk production and cow behaviour in an automatic milking system. Livest. Sci. 217:44-54.

Krohn, C. C., and L. Munksgaard. 1993. Behavior of dairy cows kept in extensive (loose housing/pasture) or intensive (tie stall) environments. 2. Lying and lying down behavior. Appl. Anim. Behav. Sci. 37:1-16.

Lyons, N. A., K. L. Kerrisk, and S. C. Garcia. 2014. Milking frequency management in pasture based automatic milking systems: A review. Livest. Sci. 159:102-116.

Mathijs, E. 2004. Socio-economic aspects of automatic milking. Pages 46-55 in Automatic Milking - A Better Understanding. A. Meijering, H. Hogeveen, and C. J. A. M. de Koning, ed. Wageningen Academic Publishers, Wageningen, the Netherlands.

Mitlohner, F. M., J. L. Morrow-Tesch, S. C. Wilson, J. W. Dailey, and J. J. McGlone. 2001. Behavioral sampling techniques for feedlot cattle. J. Anim. Sci. 79:1189-1193.

National Imagery and Mapping Agency. 2017. Glossary of marine navigation. The American Practical Navigator Vol. 2 originally by Nathaniel Bowditch, 2017 Edition. Accessed Jan. 13, 2019. http: //msi.nga.mil/MSISiteContent/StaticFiles/NAV_PUBS/APN/ Gloss-1.pdf \#9.

NRC. 2001. Nutrient Requirements of Dairy Cattle: 7th rev. ed. The National Academies Press, Washington, DC.

Overrein, H., G. Aunsmo, and G. Næss. 2018. Economic considerations of part-time grazing on exercise and production pasture on farms with automated milking: An analysis based on Norwegian and Swedish conditions (In Norwegian). In FoU-rapport. Vol. 28. Nord Universitet, Bod $\varnothing$, Norway.

Pérez-Ramírez, E., J. L. Peyraud, and R. Delagarde. 2009. Restricting daily time at pasture at low and high pasture allowance: Effects on pasture intake and behavioral adaptation of lactating dairy cows. J. Dairy Sci. 92:3331-3340.

Phelan, P., I. A. Casey, and J. Humphreys. 2013. The effect of target postgrazing height on sward clover content, herbage yield and dairy production from grass-white clover pasture. J. Dairy Sci. 96:1598-1611.

Prescott, N. B., T. T. Mottram, and A. J. F. Webster. 1998. Relative motivations of dairy cows to be milked or fed in a Y-maze and an automatic milking system. Appl. Anim. Behav. Sci. 57:23-33.

Prickett, R. W., F. B. Norwood, and J. L. Lusk. 2010. Consumer preferences for farm animal welfare: Results from a telephone survey of US households. Anim. Welf. 19:335-347.

Prince, J. H., C. D. Diesem, I. Eglitis, and G. L. Ruskell. 1960. Anatomy and histology of the eye and orbit in domestic animals. C. C. Thomas, Springfield, IL.

Reijs, J. W., C. H. G. Daatselaar, J. F. M. Helming, J. H. Jager, and A. C. G. Beldman. 2013. Grazing dairy cows in North-West Europe: Economic farm performance and future developments with emphasis on the Dutch situation. LEI Wageningen UR, The Hague.

Rook, A. J. 2000. Principles of foraging and grazing behaviour. Pages 229-246 in Grass Its Production and Utilization. 3rd ed. A. Hopkins, ed. Blackwell Science Ltd., Oxford, UK.

Rook, A. J., and C. A. Huckle. 1995. Synchronization of ingestive behaviour by grazing dairy cows. Anim. Sci. 60:25-30.

Sairanen, A., H. Khalili, P. Virkajärvi, and J. Hakosalo. 2006. Comparison of part-time grazing and indoor silage feeding on milk production. Agric. Food Sci. 15:280-292.

Sjaunja, L. O, L. Baevre, L. Junkkarinen, J. Pedersen, and J Setälä. 1990. A Nordic proposal for an energy-corrected milk (ECM) formula. in Proc. 27th Session International Committee for Recording and Productivity of Milk Animals (ICRPMA), Paris, France.

Spörndly, E. 1996. The effect of fouling on herbage intake of dairy cows on late season pasture. Acta Agric. Scand. A Anim. Sci 46:144-153.

Spörndly, E., S. Andersson, N. Pavard, and S. Le Goc. 2015. Production pasture versus exercise and recreation pasture for cows in automatic milking systems. Grassl. Sci. Eur. 20:125-127.

Spörndly, E., and M. Karlsson. 2015. Production and cow-traffic management during the pasture season in large herds with automatic milking. Grassl. Sci. Eur. 20:131-133.

Spörndly, E., and E. Wredle. 2004. Automatic milking and grazingEffects of distance to pasture and level of supplements on milk yield and cow behavior. J. Dairy Sci. 87:1702-1712.

Spörndly, E., and E. Wredle. 2005. Automatic milking and grazingEffects of location of drinking water on water intake, milk yield and cow behavior. J. Dairy Sci. 88:1711-1722.

Spörndly, R., ed. 2003. Feed tables for ruminants (In Swedish). Report 257, Department of Animal Nutrition and Management, Swedish University of Agricultural Sciences, Uppsala, Sweden.

Swedish Board of Agriculture. 2014. The effect of the pasture legislation in the Swedish welfare Ordinance for farm animals-An analysis of the economic implications on three model farms. Report 2014:16. (In Swedish)

Taweel, H. Z., B. M. Tas, J. Dijkstra, and S. Tamminga. 2004. Intake regulation and grazing behavior of dairy cows under continuous stocking. J. Dairy Sci. 87:3417-3427.

Vanhonacker, F., W. Verbeke, E. Van Poucke, and F. A. M. Tuyttens. 2008. Do citizens and farmers interpret the concept of farm animal welfare differently? Livest. Sci. 116:126-136.

Virkajärvi, P. 2004. Growth and utilization of timothy-meadow fescue pastures. Dissertation, Publication no. 19, Department of Applied Biology, University of Helsinki, Helsinki, Finland.

Volden, H., ed. 2011. NorFor - The Nordic feed evaluation system. EAAP publication No. 130, Wageningen Academic Publishers, Wageningen, the Netherlands. 